\title{
Faktor-Faktor yang Berhubungan dengan Kejadian ISPA pada Balita
}

\author{
Dita Lazamidarmi ${ }^{1,2^{*}}$, Rico Januar Sitorus ${ }^{3}$, Heru Listiono ${ }^{4}$ \\ ${ }_{1,3,4}$ Universitas Kader Bangsa, Jln HM Ryacudu No 887 Ulu Palembang Sumatera Selatan \\ ${ }^{2}$ Dinas Lingkungan Hidup dan Pertanahan, Jl.Aerobik No.4 Kampus POM IX Palembang Sumatera Selatan \\ "Correspondence email: ditalaza29@gmail.com
}

\begin{abstract}
Abstrak. ISPA adalah penyakit infeksi pada saluran pernafasan atas maupun bawah yang di sebabkan oleh masuknya kuman mikroorganisme (bakteri dan virus) ke dalam organ saluran pernafasan yang berlangsung selama 14 hari.. Penelitian ini bertujuan untuk mengetahui hubungan antara Ventilasi, Jenis lantai rumah, Jenis bahan bakar untuk memasak, Kelengkapan Imunisasi dan Riwayat penyakit infeksi terhadap kejadian ISPA pada Balita. Jenis penelitian ini bersifat Kuantitatif, menggunakan metode Survey Analitik dengan pendekatan Cross-Sectional. Lokasi penelitian di Wilayah kerja Puskesmas Alang-Alang Lebar Kota Palembang dengan jumlah responden 78. Sumber data primer diperoleh dengan kuesioner dan data sekunder diperoleh dari Profil dan Catatan Puskesmas Alang-Alang Lebar Kota Palembang. Analisis data terdiri dari analisis univariat dan bivariat dengan menggunakan uji chi square. Hasil uji chi square menunjukkan bahwa variabel yang berhubungan dengan Kejadian ISPA pada Balita adalah Ventilasi $(p=0,000 \leq 0,05)$, dan Riwayat Penyakit Infeksi $(p=0,039 \leq 0,05)$. Berdasarkan hasil penelitian dan pembahasan diambil kesimpulan bahwa Ada hubungan antara ventilasi dan riwayat penyakit infeksi dengan kejadian ISPA pada balita di Wilayah Kerja Puskesmas Alang-alang Lebar Kota Palembang tahun 2020.
\end{abstract}

Kata kunci: Bahan Bakar; Imunisasi; Infeksi; Lantai; Ventilasi

Abstract. ISPA is an infectious disease of the upper and lower respiratory tract which is caused by the entry of microorganisms (bacteria and viruses) into the respiratory tract organs which lasts for 14 days. This study aims to determine the relationship between ventilation, type of house floor, type of fuel. for cooking, completeness of immunization and history of infectious disease against the incidence of ARI in children under five. This type of research is quantitative, using the analytical survey method with a cross-sectional approach. The research location is in the working area of the Alang-Alang Lebar Community Health Center in Palembang City with a total of 78 respondents. The primary data source was obtained by means of a questionnaire and secondary data was obtained from the profile and records of the Alang-Alang Lebar Community Health Center Palembang. Data analysis consisted of univariate and bivariate analysis using the chi square test. The results of the chi square test showed that the variables associated with the incidence of ARI in children under five were ventilation $(p=0.000 \leq 0.05)$, and a history of infectious diseases $(p=0.039 \leq 0.05)$. Based on the results of the study and discussion, it was concluded that there was a simultaneous relationship between ventilation and a history of infectious diseases simultaneously with the incidence of ARI in children under five in the Alang-alang Lebar Community Health Center Palembang City in 2020.

Keywords: Fuels; Immunizations; Infections; Flooring; Ventilation

\section{PENDAHULUAN}

ISPA adalah penyakit infeksi pada saluran pernafasan atas maupun bawah yang disebabkan oleh masuknya kuman mikroorganisme (bakteri dan virus) ke dalam organ saluran pernafasan yang berlangsung selama 14 hari. Infeksi Saluran Pernafasan Akut (ISPA) merupakan salah satu penyebab kematian terbesar pada anak di negara berkembang. Bahaya penyakit ISPA pada Balita antara lain dapat mengakibatkan gagal napas dan gagal jantung. ISPA menyebabkan empat dari lima belas juta perkiraan kematian pada anak berusia di bawah 5 tahun setiap tahunnya, sebanyak dua pertiga kematian tersebut adalah bayi (Depkes RI, 2007).

Faktor-faktor yang mempengaruhi kejadian ISPA pada balita dipengaruhi oleh tiga faktor antara lain: Faktor Host (Manusia), jenis kelamin anak balita, berat badan lahir, pendidikan ibu, Faktor Environment (Lingkungan), ventilasi, jenis lantai rumah, jenis bahan bakar untuk memasak, kebiasaan merokok anggota keluarga, penyuluhan dan Faktor Agent (Penyebab
Penyakit), Mikoroorganisme Virus, Bakteri, Jamur (Bustan, 2006).

Sesuai pendapat Gordon (Notoatmodjo, 2002), bahwa suatu penyakit timbul akibat beroperasinya berbagai faktor baik dari Agent (Penyebab penyakit), Host (Induk semang), dan Environment (Lingkungan). Pendapat ini tergambar di dalam istilah yang di kenal luas dewasa ini, yaitu penyebab majemuk ("multiple causation of disease") sebagai lawan dari penyebab tunggal ("single causation").

Rantai penularan penyakit ISPA dimulai dari masuknya kuman / mikroorganisme (Agent) ke dalam tubuh manusia (Host) melalui pintu masuk (Port de Entry) yaitu saluran pernafasan dan berkembangbiak. Penularan tersebut disebabkan karena lingkungan (Environment) (Azrul, 2004).

Dalam program pemberantasan Infeksi Saluran Pernafasan Akut (ISPA) terlihat banyak faktor yang harus diperhatikan dalam pencegahan dan penanggulangan ISPA pada anak balita yaitu membawa anak balita ke sarana kesehatan, memberikan gizi yang 
baik, rumah harus berjendela agar rumah bebas polusi, lingkungan sehat untuk mencegah ISPA (Ditjend PPM dan PL, Depkes RI, 2012).

Menurut World Health Organization (WHO, 2007), Infeksi Saluran Pernafasan Akut (ISPA) merupakan salah satu masalah kesehatan yang ada di negara berkembang dan negara maju. Hal ini disebabkan masih tingginya angka kesakitan dan angka kematian karena ISPA khususnya pneumonia, terutama pada bayi dan balita. Di Amerika Serikat, pneumonia menempati peringkat ke-6 dari semua penyebab kematian dan peringkat pertama dari seluruh penyakit infeksi. Di Spanyol, angka kematian akibat pneumonia mencapai 25 $\%$, sedangkan di Inggris dan Amerika Serikat mencapai $12 \%$ sedangkan angka kematian akibat ISPA dan pneumonia pada tahun 2001 untuk negara Jepang yaitu $10 \%$, Singapura sebesar $10,6 \%$, Thailand sebesar 4,1 $\%$, Brunei sebesar 3,2 \% dan Philipina tahun 2002 sebesar $11,1 \%$.

Infeksi Saluran Pernafasan Akut (ISPA) dikenal sebagai salah satu penyebab kematian utama pada anak bayi dan balita di negara berkembang. Hasil Survei Kesehatan Rumah Tangga (SKRT) tahun 2003, menunjukkan bahwa 21,2 \% kematian bayi dan 30,0 \% kematian anak balita di sebabkan ISPA (Depkes RI, 2007).

Tujuan penelitian ini adalah untuk mengetahui hubungan antara variabel dependen (Kejadian ISPA pada Balita) dengan variabel independen (Ventilasi, Jenis Lantai Rumah, Jenis Bahan Bakar Untuk Memasak, Kelengkapan Imunisasi dan Riwayat Penyakit Infeksi).

\section{METODE}

Desain Penelitian ini bersifat kuantitatif menggunakan metode survey analitik dengan pendekatan Cross Sectional, dimana variabel independen dan variabel dependen di ukur dan diobservasi secara bersamaan pada saat penelitian dengan menggunakan kuesioner (Notoatmodjo, 2010).

Populasi dalam penelitian ini adalah seluruh balita usia 0-5 Tahun dengan responden yaitu ibu balita/keluarga yang berobat ke Puskesmas Alang-alang Lebar Kota Palembang yang dengan jumlah populasi sebanyak 78 kasus pada balita.

Sampel adalah sebagian dari populasi yang mewakili seluruh populasi. Sampel dalam penelitian ini yang akan diambil adalah seluruh ibu/orang tua yang mempunyai balita usia 0-5 tahun yang berada di Wilayah Kerja Puskesmas Alang-Alang Lebar Kota Palembang yang membawa balitanya berobat ke Puskesmas Alangalang Lebar Kota Palembang. Jumlah sampel yang diteliti pada Penelitian adalah sebanyak 78 orang sebagai responden.

Pengumpulan data dilakukan untuk memperoleh informasi yang bersumber dari data primer yaitu data yang diperoleh secara langsung dari responden dengan cara mewawancarai langsung responden yang menjadi sampel penelitian melalui pengisian daftar pertanyaan (kuisioner) serta observasi langsung tentang Kejadian ISPA dan faktor yang mempengaruhinya (Ventilasi, Jenis Lantai Rumah, Jenis Bahan Bakar Untuk Memasak, Kelengkapan Imunisasi dan Riwayat Penyakit Infeksi). Data primer merupakan lembar kuesioner yang berisi pertanyaan tentang ISPA pada Balita. Kuesioner dibagikan kepada responden dan dijawab oleh responden untuk mengetahui apa saja faktor-faktor yang mempengaruhi ISPA pada balita. Setelah dijawab oleh responden, kuesioner dikumpulkan oleh peneliti dan dilakukan pengolahan data.

Proses penyederhanaan data ke dalam bentuk yg lebih mudah dibaca dan diinterpretasikan dengan menggunakan perangkat komputer kemudian dilakukan analisis (Sabri, 2006) : Analisis Univariat adalah analisis yang digunakan untuk mengetahui distribusi frekuensi dan persentase dari masing-masing variabel yang diteliti baik variabel dependen maupun variabel independen dan Analisis Bivariat adalah analisis yang digunakan untuk mengetahui hubungan antara variabel dependen dan independen yang terjadi memang bermakna secara statistik, kemudian dianalisis dengan menggunakan uji Chi-square dengan tingkat kemaknaan nilai $\alpha(0,05)$, dengan kriteria uji yang bertujuan untuk melihat adanya hubungan kejadian ISPA pada balita di Wilayah Kerja Puskesmas Alang-Alang Lebar Kota Palemang.

Dasar pengambilan hipotesis peneliti pada tingkat signifikasi (nilai $\rho$ ) yaitu : Bila nilai $\rho$ value $\leq 0,05$, berarti ada hubungan yang bermakna (signifikan) antara variabel dependen dan variabel independen dan Bila nilai $\rho$ value $>0,05$ berarti tidak ada hubungan yang bermakna (signifikan) antara variabel dependen dengan variabel independen.

\section{HASIL DAN PEMBAHASAN Analisis Univariat}

Analisis ini dilakukan untuk memperoleh gambaran distribusi frekuensi dan persentase responden menurut semua variabel penelitian baik variabel dependen (Kejadian ISPA pada Balita) maupun variabel independen (Ventilasi, Jenis Lantai Rumah, Jenis Bahan Bakar Untuk Memasak, Kelengkapan Imunisasi dan Riwayat Penyakit Infeksi) yang dikumpulkan dalam tabel di bawah ini (Tabel 1).

Table 1. Distribusi Frekuensi Variabel Independen dan Dependen

\begin{tabular}{clcc}
\hline No & \multicolumn{1}{c}{ Variabel Penelitian } & $\begin{array}{c}\text { Jumlah } \\
(\mathbf{N})\end{array}$ & $\begin{array}{c}\text { Persentase } \\
(\mathbf{\%})\end{array}$ \\
\hline 1 & Ventilasi & & \\
& - Kurang & 60 & 76,9 \\
& - Cukup & 18 & 23,1 \\
2 & Jenis Lantai Rumah & & \\
& - Tidak memenuhi & 56 & 71,8 \\
& - Memenuhi & 22 & 28,2
\end{tabular}


3 Jenis Bahan Bakar Untuk

Memasak

- Tidak Baik

- Baik

4 Kelengkapan Imunisasi

- Kurang lengkap

- Lengkap

5 Riwayat Penyakit Infeksi

- Ada

- Tidak Ada

6 Kejadian ISPA Pada Balita

- ISPA

- Tidak ISPA

Sumber data: hasil penelitian.
Dari tabel 1 di atas terlihat bahwa ventilasi kurang luas 60 orang (76,9\%).Jenis lantai rumah tidak memenuhi syarat kesehatan (semen dan papan) 56 orang $(71,8 \%)$. Jenis bahan bakar untuk memasak tidak baik (minyak tanah dan kayu bakar) 48 orang (61,5\%). Pemberian imunisasi kurang lengkap berjumlah 46 orang (59,0\%). Ada riwayat penyakit infeksi berjumlah 57 orang $(73,1 \%)$. Kejadian ISPA pada balita ISPA 53 orang $(67,9 \%)$.

\section{Analisis Bivariat}

Tabel 2. Hubungan Variabel Independen dengan Variabel Dependen

\begin{tabular}{|c|c|c|c|c|c|c|c|c|c|}
\hline \multirow{3}{*}{ No } & \multirow{3}{*}{ Variabel Independen } & \multicolumn{4}{|c|}{ Kejadian ISPA } & \multirow{2}{*}{\multicolumn{2}{|c|}{ Total }} & \multirow{3}{*}{$\begin{array}{c}\text { Odd Ratio } \\
95 \% \text { CI }\end{array}$} & \multirow{3}{*}{$\begin{array}{c}\rho \\
\text { Value }\end{array}$} \\
\hline & & \multicolumn{2}{|c|}{ ISPA } & \multicolumn{2}{|c|}{ Tidak ISPA } & & & & \\
\hline & & $\mathrm{n}$ & $\%$ & $\mathrm{n}$ & $\%$ & $\mathrm{~N}$ & $\%$ & & \\
\hline 1 & $\begin{array}{l}\text { Ventilasi } \\
\text { 1. Kurang } \\
\text { 2. Cukup } \\
\end{array}$ & $\begin{array}{c}48 \\
5 \\
\end{array}$ & $\begin{array}{c}80 \\
27,8 \\
\end{array}$ & $\begin{array}{l}12 \\
13 \\
\end{array}$ & $\begin{array}{c}20 \\
72,2 \\
\end{array}$ & $\begin{array}{l}60 \\
18 \\
\end{array}$ & $\begin{array}{l}100 \\
100 \\
\end{array}$ & $\begin{array}{c}10,400 \\
(3,101-34,874)\end{array}$ & 0,000 \\
\hline 2 & $\begin{array}{l}\text { Jenis Lantai rumah } \\
\text { 1. Tidak memenuhi syarat } \\
\text { 2. Memenuhi syarat }\end{array}$ & $\begin{array}{l}38 \\
15\end{array}$ & $\begin{array}{l}67,9 \\
68,2\end{array}$ & $\begin{array}{c}18 \\
7\end{array}$ & $\begin{array}{l}32,1 \\
31,8\end{array}$ & $\begin{array}{l}56 \\
22\end{array}$ & $\begin{array}{l}100 \\
100\end{array}$ & $\begin{array}{c}0,985 \\
(0,342-2,838)\end{array}$ & 1,000 \\
\hline 3 & $\begin{array}{l}\text { Jenis bahan bakar memasak } \\
\text { 1. Tidak baik } \\
\text { 2. Baik }\end{array}$ & $\begin{array}{l}30 \\
23 \\
\end{array}$ & $\begin{array}{l}62,5 \\
76,7 \\
\end{array}$ & $\begin{array}{c}18 \\
7 \\
\end{array}$ & $\begin{array}{l}37,5 \\
23,3 \\
\end{array}$ & $\begin{array}{l}48 \\
30 \\
\end{array}$ & $\begin{array}{l}100 \\
100 \\
\end{array}$ & $\begin{array}{c}0,507 \\
(0,181-1,4180 \\
\end{array}$ & 0,291 \\
\hline 4 & $\begin{array}{l}\text { Kelengkapan Imunisasi } \\
\text { 1. Kurang lengkap } \\
\text { 2. Lengkap }\end{array}$ & $\begin{array}{l}35 \\
18 \\
\end{array}$ & $\begin{array}{l}76,1 \\
56,3 \\
\end{array}$ & $\begin{array}{l}11 \\
14 \\
\end{array}$ & $\begin{array}{l}23,9 \\
43,8 \\
\end{array}$ & $\begin{array}{l}46 \\
32 \\
\end{array}$ & $\begin{array}{l}100 \\
100 \\
\end{array}$ & $\begin{array}{c}2,475 \\
(0,935-6,548)\end{array}$ & 0,110 \\
\hline 5 & $\begin{array}{l}\text { Riwayat Penyakit Infeksi } \\
\text { 1. Ada } \\
\text { 2. Tidak ada }\end{array}$ & $\begin{array}{l}43 \\
10\end{array}$ & $\begin{array}{l}75,4 \\
47,6\end{array}$ & $\begin{array}{l}14 \\
11\end{array}$ & $\begin{array}{l}24,6 \\
52,4\end{array}$ & $\begin{array}{l}57 \\
21\end{array}$ & $\begin{array}{l}100 \\
100\end{array}$ & $\begin{array}{c}3,379 \\
(1,185-9,630)\end{array}$ & 0,039 \\
\hline
\end{tabular}

Sumber data: hasil penelitian.

\section{Hubungan Ventilasi Dengan Kejadian ISPA Pada Balita}

Dari tabel 2 dapat dilihat Distribusi Kejadian ISPA pada balita bahwa dari 78 responden dengan ventilasi kurang sejumlah 48 orang $(80,0 \%)$, lebih banyak bila di bandingkan dengan ventilasi cukup sejumlah 5 orang $(27,8 \%)$.

Hasil uji statistik dengan uji chi square diperoleh hasil $\rho$ Value $0,000 \leq 0,05$ maka secara statistik pada $\alpha$ 0,05 ada hubungan yang bermakna antara ventilasi dengan kejadian ISPA pada balita.

Hasil analisa juga diperoleh nilai Odds Ration (OR) sebesar 10,400, artinya ventilasi yang kurang luas berpeluang 10,400 kali akan terkena kejadian ISPA bila di bandingkan dengan ventilasi yang cukup luas di wilayah kerja Puskesmas Alang-alang Lebar Kota Palembang tahun 2020.

Menurut Wulandari, 2018 ventilasi dalam ruangan yang baik harus memenuhi syarat, yaitu: luas lubang ventilasi $\geq 10 \%$ dari luas lantai rumah, lingkungan di sekitar rumah tidak tercemar polusi, aliran udara diusahakan cross ventilation dan kelembaban udara dijaga jangan sampai terlalu tinggi maupun terlalu rendah. Ventilasi rumah yang memenuhi syarat dapat mencegah berkembangnya kuman / bakteri patogen yang dapat meningkatkan resiko terjadinya ISPA. Setiap pagi, ventilasi diusahakan untuk selalu dibuka agar terjadi pertukaran aliran udara. Selain itu, kepadatan hunian dalam rumah juga harus diperhatikan karena dapat mempengaruhi keseimbangan udara sehingga dapat meningkatkan resiko terjadinya ISPA (Dinata, 2007).

Berdasarkan hasil penelitian dan teori yang ada, maka peneliti berpendapat bahwa ada hubungan antara ventilasi dengan kejadian ISPA pada balita.

\section{Hubungan Jenis Lantai Rumah Dengan Kejadian ISPA Pada Balita}

Dari tabel 2 juga dapat dillihat Distribusi Kejadian ISPA pada balita dengan Jenis lantai rumah yang tidak memenuhi syarat sejumlah 38 orang (67,9\%), lebih banyak bila di bandingkan dengan Jenis lantai rumah yang memenuhi syarat sejumlah 15 orang $(68,2 \%)$.

Hasil uji statistik dengan uji chi square di peroleh hasil $\rho$ Value 1,000>0,05 maka secara statistik pada $\alpha$ 0,05 , tidak ada hubungan yang bermakna antara jenis lantai rumah dengan kejadian ISPA pada balita. 
Hasil analisa juga diperoleh nilai Odds Ration (OR) sebesar 0,985 artinya jenis lantai rumah yang tidak memenuhi syarat berpeluang 0,985 kali akan terkena kejadian ISPA bila di bandingkan dengan jenis lantai yang memenuhi syarat di wilayah kerja Puskesmas Alang-alang Lebar Kota Palembang tahun 2020.

Menurut Surjadi (2019), jenis lantai rumah yang baik terbuat dari bahan yang tidak mudah terbakar dan yang tidak mudah lembab karena bahan yang mengandung kelembaban yang tinggi dapat menjadi tempat kuman penyakit untuk berkembang biak sehingga meningkatkan resiko terjadinya ISPA ditambah lagi dengan tidak ada sinar matahari yang masuk ke dalam rumah (Azrul, 2004).

Berdasarkan hasil penelitian dan teori yang ada, maka peneliti berpendapat bahwa tidak ada hubungan antara jenis lantai rumah dengan kejadian ISPA pada balita.

\section{Hubungan Jenis Bahan Bakar Masak Dengan Kejadian ISPA}

Dari tabel 2 dapat dillihat Distribusi Kejadian ISPA pada balita dengan jenis bahan bakar untuk memasak yang tidak baik sejumlah 30 orang $(62,5 \%)$, lebih banyak bila dibandingkan dengan bahan bakar untuk memasak yang baik sejumlah 23 orang $(76,7 \%)$.

Hasil uji statistik dengan uji chi square diperoleh hasil $\rho$ Value 0,291 >0,05 maka secara statistik pada $\alpha$ 0,05 , tidak ada hubungan yang bermakna antara bahan bakar untuk memasak dengan kejadian ISPA pada balita..

Hasil analisa juga diperoleh nilai Odds Ration (OR) sebesar 0,507, artinya jenis bahan bakar untuk memasak yang tidak baik berpeluang 0,507 kali akan terkena kejadian ISPA pada balita bila dibandingkan dengan bahan bakar untuk memasak yang baik di wilayah kerja Puskesmas Alang-alang Lebar Kota Palembang tahun 2020.

penelitian Indrawan (2010) di Wilayah Kerja Puskesmas Simpang Periuk Kota Lubuk Linggau yang menyatakan tidak ada hubungan antara jenis bahan bakar untuk memasak dengan Kejadian ISPA pada balita.

Aktivitas manusia yang selalu dilakukan di setiap rumah adalah memasak. Di pedesaan, bahan bakar untuk memasak sampai saat ini, masih banyak di gunakan oleh masyarakat Indonesia adalah minyak tanah dan kayu bakar. Pembakaran minyak tanah dan kayu bakar disamping menghasilkan polutan dalam bentuk debu / partikel juga menghasilkan zat pencemar kimia berupa carbon monoksida, dioksida, sulfur, oxida nitrogen, dan hydrocarbon. Semua zat di atas memberikan dampak yang dapat mengganggu sistem pernafasan (Saleh, 2017).

Jenis bahan bakar adalah bahan bakar yang digunakan untuk memasak di dapur seperti gas, litrik, minyak tanah dan kayu bakar. Kategori bahan bakar tersebut berdasarkan besar kecilnya faktor risiko adalah sebagai berikut: bahan bakar baik (gas dan listrik), dan kategori kurang (minyak tanah dan kayu bakar) (Depkes RI, 2012).

\section{Hubungan Kelengkapan Imunisasi Dengan Kejadian ISPA Pada Balita}

Dari tabel 2 juga dapat dillihat Distribusi Kejadian ISPA pada balita dengan kelengkapan imunisasi kurang lengkap sejumlah 35 orang $(76,1 \%)$, lebih banyak bila dibandingkan dengan yang kelengkapan imunisasi lengkap sejumlah 18 orang $(56,3 \%)$.

Hasil uji statistik dengan uji chi square diperoleh hasil $\rho$ Value $0,110>0,05$ maka secara statistik pada $\alpha$ 0,05 , tidak ada hubungan yang bermakna antara kelengkapan imunisasi dengan kejadian ISPA pada balita.

Hasil analisa juga diperoleh nilai Odds Ration (OR) sebesar 2,475, artinya kelengkapan imunisasi yang kurang lengkap berpeluang 2,475 kali akan terkena kejadian ISPA pada balita bila di bandingkan dengan yang kelengkapan imunisasi lengkap di wilayah kerja Puskesmas Alang-alang Lebar Kota Palembang tahun 2020.

Hasil penelitian ini sesuai dengan penelitian yang dilakukan oleh Eny Setyaningsih (2001). Status imunisasi bukan merupakan faktor resiko yang berhubungan dengan kejadian ISPA pada balita di Kabupaten Banjarnegara. Hal ini kemungkinan disebabkan karena tingginya cakupan imunisasi pada Anak balita. Sebagian besar responden mengetahui bahwa imunisasi sangat penting bagi Anak balita untuk mencegah terjadinya penyakit infeksi. Hal ini dapat dilihat dari besarnya jumlah responden dengan anak balita yang status imunisasinya lengkap yaitu sebesar $89,3 \%$. Sedangkan responden dengan Anak balita yang status imunisasi tidak lengkap yaitu sebesar 10,7 \%, dengan alasan bahwa setelah imunisasi Anak balita menjadi panas dan alasan lain dari sebagian responden karena jarak transportasi jauh ke tempat sarana kesehatan (Posyandu, Puskesmas) dan kesibukan ibu balita. Imunisasi sangat berguna dalam menentukan ketahanan tubuh bayi terhadap gangguan penyakit (Depkes RI, 2006).

Para ahli kesehatan menyebutkan bahwa di banyak negara, dua penyebab utama tingginya angka kematian anak adalah gangguan gizi dan infeksi. Hal ini dapat dicegah dengan imunisasi yang merupakan hal mutlak dalam memelihara kesehatan dan gizi anak (Sjahmien Moehji, 2009).

\section{Hubungan Riwayat Penyakit Infeksi Dengan Kejadian ISPA Pada Balita}

Dari tabel 2 juga dapat dillihat Distribusi Kejadian ISPA pada balita dengan riwayat penyakit infeksi dinyatakan ada sejumlah 43 orang $(75,4 \%)$, lebih banyak bila dibandingkan dengan riwayat penyakit infeksi tidak ada sejumlah 10 orang $(47,6 \%)$. 
Hasil uji statistik dengan uji chi square diperoleh hasil $\rho$ Value $0,039 \leq 0,05$ maka secara statistik pada $\alpha$ 0,05 , ada hubungan yang bermakna antara riwayat penyakit infeksi dengan kejadian ISPA pada balita.

Hasil analisa juga diperoleh nilai Odds Ration (OR) sebesar 3,379, artinya adanya riwayat penyakit infeksi yang diderita berpeluang 3,379 kali akan terkena kejadian ISPA bila dibandingkan dengan yang tidak ada riwayat penyakit infeksi di wilayah kerja Puskesmas Alang-alang Lebar Kota Palembang tahun 2020.

Hasil analisa juga di peroleh nilai OR 3,379, artinya adanya riwayat penyakit infeksi yang diderita berpeluang 3,379 kali menyebabkan ISPA pada balita bila dibandingkan dengan yang tidak ada riwayat penyakit infeksi di wilayah kerja Puskesmas Alangalang Lebar Kota Palembang tahun 2020

Penelitian Maharani (2017) Infeksi Saluran Pernafasan Akut (ISPA) merupakan penyakit yang sering terjadi pada anak. Jumlah kasus ISPA di masyarakat diperkirakan sebanyak $10 \%$ dari populasi. ISPA adalah penyakit menular yang menjadi penyebab utama kematian pada anak usia $<5$ tahun di dunia. Ada banyak faktor yang menyebabkan terjadinya ISPA. kejadian ISPA dipengaruhi oleh agent penyebab seperti virus dan bakteri, faktor pejamu (usia anak, jenis kelamin, status gizi, imunisasi dll) serta keadaan lingkungan (polusi udara dan ventilasi). Usia anak merupakan faktor predisposisi utama yang menentukan tingkat keparahan serta luasnya infeksi saluran nafas. Selain itu, status gizi juga berperan dalam terjadinya suatu penyakit. Hal ini berhubungan dengan respon imunitas seorang anak. Penyakit ISPA sering dikaitkan dengan kejadian malnutrisi dan stunting pada anak (Fikawati, 2017). Penelitian ini juga sejalan dengan penelitian yang dilakukan oleh Welasasih (2014).

\section{SIMPULAN}

Berdasarkan hasil penelitian mengenai Faktorfaktor yang berhubungan dengan kejadian ISPA pada balita di wilayah kerja Puskesmas Alang-Alang Lebar Kota Palembang tahun 2020 diperoleh kesimpulan sebagai berikut

1. Kepemilikan Ventilasi kurang sejumlah 48 orang (80,0\%), sementara Ventilasi cukup sejumlah 5 orang (27,8\%). Berdasarkan Hasil uji statistik dengan uji chi square diperoleh hasil $\rho$ Value $0,000 \leq 0,05$ dan nilai Odds Ratio $(\mathrm{OR})=10,400$. Artinya ada hubungan ventilasi secara parsial dengan kejadian ISPA pada balita di wilayah kerja Puskesmas Alangalang Lebar Kota Palembang tahun 2020.

2. Kepemilikan Jenis lantai rumah yang tidak memenuhi syarat sejumlah 38 orang $(67,9 \%)$, sementara jenis lantai rumah yang memenuhi syarat sejumlah 15 orang $(68,2 \%)$. Berdasarkan Hasil uji statistik dengan uji chi square diperoleh hasil $\rho$ Value 1,000 > 0,05 dan nilai Odds Ratio $(\mathrm{OR})=0,985$. Artinya tidak ada hubungan antara jenis lantai rumah secara parsial dengan kejadian ISPA pada balita di wilayah kerja Puskesmas Alang-alang Lebar Kota Palembang tahun 2020.

3. Penggunaan jenis bahan bakar untuk memasak yang tidak baik sejumlah 30 orang $(62,5 \%)$, sementara penggunaan jenis bahan bakar untuk memasak yang baik sejumlah 23 orang $(76,7 \%)$. Berdasarkan Hasil uji statistik dengan uji chi square diperoleh hasil $\rho$ Value 0,291 $>0,05$ maka secara statistik pada $\alpha 0,05$ dan nilai Odds Ratio $(\mathrm{OR})=0,507$. Artinya Tidak ada hubungan antara jenis bahan bakar untuk memasak secara parsial dengan kejadian ISPA pada balita di wilayah kerja Puskesmas Alang-alang Lebar Kota Palembang tahun 2020.

4. Kepemilikan kelengkapan imunisasi kurang lengkap sejumlah 35 orang $(76,1 \%)$, sementara kepemilikan kelengkapan imunisasi yang lengkap sejumlah 18 orang $(56,3 \%)$. Berdasarkan Hasil uji statistik dengan uji chi square di peroleh hasil $\rho$ Value 0,110 >0,05 dan nilai Odds Ratio $(\mathrm{OR})=2,475$. Artinya Tidak ada hubungan antara Kepemilikan kelengkapan imunisasi secara parsial dengan kejadian ISPA pada balita di wilayah kerja Puskesmas Alang-alang Lebar Kota Palembang tahun 2020.

5. Adanya Riwayat penyakit infeksi sejumlah 43 orang $(75,4 \%)$, sementara yang tidak ada Riwayat penyakit infeksi sejumlah 10 orang $(47,6 \%)$. Berdasarkan Hasil uji statistik dengan uji chi square di peroleh hasil $\rho$ Value $0,039 \leq 0,05$ dan nilai Odds Ratio (OR) $=$ 3,379. Artinya Ada hubungan antara Riwayat penyakit infeksi secara parsial dengan kejadian ISPA pada balita di wilayah kerja Puskesmas Alang-alang Lebar Kota Palembang tahun 2020.

6. Ada hubungan antara Ventilasi dan Riwayat penyakit infeksi secara simultan dengan kejadian ISPA pada balita di wilayah kerja Puskesmas Alang-alang Lebar Kota Palembang tahun 2020

\section{DAFTAR PUSTAKA}

Awang, Indrawan. (2010). Hubungan umur dan status imunisasi terhadap kejadian ISPA pada balita di usia 0-5 tahun di Puskesmas Simpang Peluk Kota Lubuk Lingau Tahun (2010). Di unduh dari http://Kumpulan Karya Tulis Ilmiah.

Azrul, 2004. Pengantar Ilmu Kesehatan Lingkungan, Mutiara Sumber Widya, Jakarta,

Bustan, 2006. Epidemiologi Penyakit Menular, PT. Rineka Cipta, Jakarta.

Depkes, R.I, 2007. Penanggulangan ISPA Pada Balita, Jakarta : EGC.

Depkes R.I, 2012. Pedoman Pemberantasan Penyakit Infeksi Saluran Pernafasan Akut Untuk Penanggulangan Pneumonia Pada Balita, Jakarta: Ditjen PPM-PLP.

Dinata, A., 2007. Aspek Teknis dalam Penyehatan Rumah. Diakses : 22 April 
Dita Lazamidarmi, Rico Januar Sitorus dan Heru Listiono, Faktor-Faktor yang Berhubungan dengan Kejadian ISPA pada Balita

2014.http://miqrasehat.Jurnal.com/2007/07/aspekteknis-dalam-penyehatan-rumah.html

Dit.Jen,PPM-PL, Departemen Kesehatan RI, 2012. Pedoman Program Pemberantasan Penyakit Infeksi Saluran Pernafasan Akut Untuk Penaggulanagn Pnemonia Pada Balita.

Eny Setyaningsih. 2001. Faktor-Faktor Yang Berhubungan dengan Kejadian Pneumonia pada Balita Pengunjung Puskesmas Klampok Kabupaten Banjarnegara Tahun 2001. Skripsi S1. Universitas Diponegoro

Fikawati, S, Syafiq, A, Karima, K 2015, Gizi Ibu dan Bayi, Rajawali Pers, Jakarta

Notoatmodjo Soekijo, 2002. Ilmu Kesehatan Masyarakat, PT, Rineka Cipta, Jakarta,

Notoatmodjo S, 2010. Metodologi Penelitian Kesehatan, Jakarta : Rineka Cipta

Maharani, 2017. Profil Balita Penderita Infeksi Saluran Nafas Akut Atas di Poliklinik Anak RSUP DR. M. Djamil Padang Tahun 2012-2013 Jurnal Kesehatan Andalas. 2017; 6 (1)

Sabri, 2006, Statistik Kesehatan, Rineka Cipta, Jakarta.

Saleh, 2017, Hubungan Sumber Polutan dalam Rumah Dengan Kejadian Infeksi Saluran Pernafasan Akut pada Balita di Kecamatan Mariso Kota Makassar, Jurnal Higine, Volume 3, No. 3, SeptemberDEesember 2017.

Sjahmien Moehji, B.Sc. 2009. Ilmu Gizi Pengetahuan Dasar Ilmu Gizi. Jakarta: Papas Sinar Sinanti

Surjadi, 2019, Kesehatan Perkotaan di Indoensia.

Welasasih B, Wirjatmadi R. 2012. Beberapa Faktor yang Berhubungan dengan Status Gizi Balita Stunting. The Indonesian Journal of Public Health, volume 8, Nomor 3, tahun 2012, 99-104 (online) (http://journal.unair.ac.id). Diakses Oktober 2014

WHO.2007.Penanganan ISPA Pada Anak di Rumah Sakit kecil di Negara berkembang.

Wulandari, 2018. Sanitasi Rumah Sakit, Pusat Pendidikan Sumber Daya Manusia Kesehatan, BPSDM Kesehatan RI Tahun 2018 